\title{
Medicinal plants used against gastrointestinal disorders by the Tamang people in Rasuwa district, central Nepal
}

\author{
Saroj Yadav and Sangeeta Rajbhandary* \\ Central Department of Botany, Tribhuvan University, Nepal
}

\begin{abstract}
The different ethnic groups dwelling in different phytogeographic belts of Nepal have their own traditional system of knowledge on application of plant resources for health care. The traditional knowledge of using plants is passed on from generation to generation as folklore. Rasuwa district is rich in variety of flora especially medicinal plants and ethnic people (mainly Tamang) are familiar with medicinal resources and possess rich ethno-pharmacological knowledge. These resources provide huge opportunities for community development and livelihood improvement. This paper will present the documentation of medicinal plant used for gastrointestinal disorders in Chilime, Gatlang and Thuman Village Development Committees in Rasuwa district, north-central Nepal.
\end{abstract}

Key-words: ethnobotany, common species, ethnopharmacology.

\section{Introduction}

The utilization of plant and plant products as medicine can be traced as far back as the beginning of human civilization and this practice has not diminished in any way in recent times (Bhattarai et al. 2006; Ekor 2013). In many societies, the indigenous knowledge about the properties of plants and the systems of their utilization has been orally passed for generations (Rajbhandari 2001). However, some forms of traditional knowledge are also expressed in stories, legends, folklore, rituals and songs (Martin 1995; Cunningham 2001).

Medicinal and aromatic plants are local heritage of global importance, they constitute the basis of health care system in many societies. The use of herbal medicines for treatment of various health challenges has been expanded rapidly across the world. About $80 \%$ of the world's population living in the developing countries rely on traditional herbal medicines (Bannerman 1982; Bodeker et al. 2005; Ekor 2013). In Nepal, medicinal plants play significant role in healthcare and people's livelihood (Manandhar 1999; Shrestha et al. 2001; Shrestha et al. 2002; Sharma et al. 2004; Bhattarai et al. 2006; Kunwar and Bussmann 2008). It is estimated that only $15-20 \%$ of the population of Nepal living in and around urban areas have access to modern healthcare facilities, whereas the rest depend on traditional medicine (Sharma et al. 2004). Traditional medical practitioners are found in every rural villages in Nepal and occupy an important position in the society. Consequently, local people in Nepal depend largely on these healers and shamanistic treatments (Rajbhandari and Ranjitkar 2006).

The different ethnic groups dwelling in different phytogeographic belts of Nepal have their own traditional system of knowledge about the use of plant resources. Several studies have been conducted in Nepal unravelling the diversity of species utilized and associated ethnobotanical knowledge and practices (Rajbhandari 2001; Manandhar 2002; Bhattarai et al. 2006; Malla et al. 2015), but these are not adequate given the extent of biocultural diversity within the country.

Yet to this date, very little information has been recorded about the traditional uses of plants from tribal communities, such as Tamang (Luitel et al. 2014). The present study was conducted to enumerate wild medicinal plant resources and document ethnomedicinal practice for gastrointestinal disorders of indigenous Tamang people in three (Chilime, Thuman and Gatlang) Village Development Committees (VDCs) of Rasuwa district, north-central Nepal.

\section{Materials and Methods}

\section{STUDY AREA}

Rasuwa district lies in the north-central part of Nepal. It is the mountainous and high Himalayan district and falls within $27^{\circ} 57^{\prime} 30^{\prime \prime}$ 'to $28^{\circ} 23^{\prime} 30^{\prime \prime} \mathrm{N}$ latitude and $85^{\circ} 07^{\prime} 00^{\prime \prime}$ ' to $85^{\circ}$ $48^{\prime} 15^{\prime \prime}$ E longitude. It is situated about $120 \mathrm{~km}$ north of the capital city Kathmandu. It is surrounded by the Langtang and Salang-Sungo ranges towards the north bordering with Tibet Autonomous Region of China. The district has an area of 151,179 hectare. Rasuwa district consists of 18 VDCs, of which in three (namely, Chilime, Gatlang and Thuman) were selected for the present study (Figure 1). The study area comprises warm temperate to alpine humid climate. Rasuwa district has rich biodiversity and is also rich in cultural heritage.

The major ethnic group in the study area is Tamang, which constitute over $60 \%$ of the total population. Tamang people

*Corresponding author: e-mail - s.rajbhandary@cdbtu.edu.np 
are one of the major indigenous ethnic groups in Nepal, which follow Buddhism. They belong to Tibeto-Burman group but with their own language, culture, tradition and a distinct life style (Thokar 2008). They are believed to be descended from a Tibetan stock and have settled down in Nepal for centuries (reviewed in Thokar 2008). The oldest use of the word 'Tamang' dates back to the 13th century (Thokar 2008). The area harbors a number of high valued medicinal plants that are widely utilized by the local communities. Due to its richness in biodiversity and cultural heritage, Rasuwa district has become an attractive site for scientific research (the most important were those of Manandhar 1980; Joshi and Edington 1990; Dangol 2002; Shrestha et al. 2002). Despite many botanical explorations, there is limited information available on ethnobotany of the area.

\section{METHODS}

Prior informed consent was obtained with the help of community workers (Martin 1995) who also facilitated interviews and discussions with the local people. The information on ethnomedicinal value was gathered using two approaches i.e., survey technique and inventory technique (Martin 1995; Cunningham 2001). The survey technique included individual and in-depth interviews and focus group discussion with local plants users, community members, traditional faith healers, village heads and traders. The inventory technique comprised of collection of specimens of medicinal plants through transects walk and determination of their identity and use. Local people (knowledgeable key interviewees) were involved in the transect walk, during which period they were asked for local name of each plant species collected, its part(s) use, and purpose and mode of use.

Altogether 92 key persons were interviewed, of which $50 \%$ were above the age of 50 and $50 \%$ were between the ages of 30 and 40 . Consent was granted by the local people for the dissemination of their traditional knowledge. A checklist was developed and used to determine what species were used to treat what kinds of diseases/disorders. Herbarium specimens were collected and deposited at the Tribhuvan University Central Herbarium (TUCH).

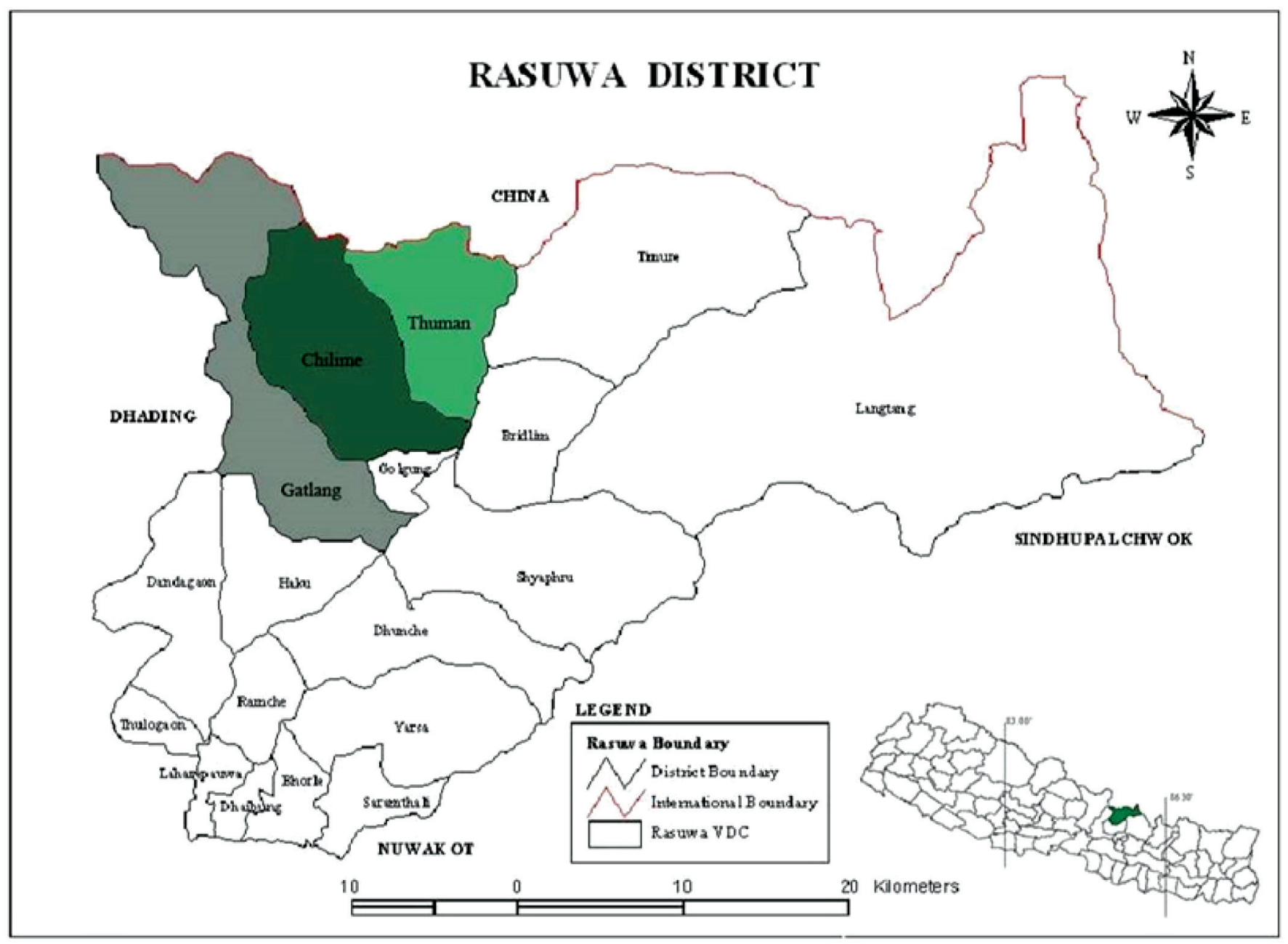

Figure 1. Map of Rasuwa district highlighting the study areas. 


\section{Results}

Altogether, 21 species of medicinal plants, belonging to 17 families and 21 genera, were recorded as useful for the treatment of gastrointestinal disorders (Table 1). Liliaceae was the largest plant family having highest number of medicinal plant species $(n=3)$, Lauraceae and Polygonaceae each with 2 species (Table 1). Angiosperms were predominant with 20 species and Pteridophytes with one species. Out of the 21 medicinal plant species identified as useful for gastrointestinal disorders, 8 species were common to all three VDCs (Appendix 1). The most important species common to three VDCs were Aconitum spicatum, Cannabis sativa, Cinnamomum tamala, Dactylorhiza hatagirea, Pteris biaurita, Rhodiola himalayensis, Vitex negundo, and Zanthoxylum armatum (Table 1).

The prevailing life forms (Figure 2) among vascular plants were perennial herbs (14 species), shrubs (4 species), trees (2 species), and climbers ( 1 species). The most frequently utilized plant parts (Figure 2) are underground roots and root tubers/ rhizomes $(52.4 \%)$, followed by leaves (19\%), fruit, seed, stem and whole plants $(9.5 \%$ each), and bark and flower $(4.8 \%$ each). The mode of use was mostly in a form of paste (Table 1).

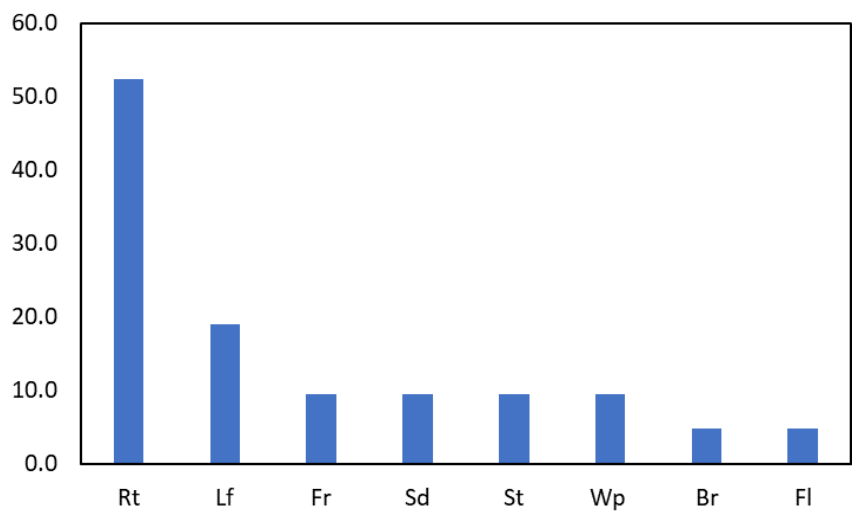

Figure 2. Medicinal parts use categories: percentage of medicinal plant parts used $(\mathrm{Br}$ - bark, $\mathrm{Fl}$ - flower, $\mathrm{Fr}$ - fruit, Lf - leaf, Rt - root/root tubers/rhizomes, $\mathrm{Sd}$ - seed, $\mathrm{St}$ - stem, $\mathrm{Wp}$ - whole plant).

\section{Discussion}

The study areas have unique type of plant diversity inhabiting from subtropical to alpine zone. People here have retained their traditional knowledge and practices to fulfil their daily needs. Altogether, 21 species of medicinal plants were identified as being used in traditional medical systems from three VDC's in Rasuwa district of central Nepal for the gastrointestinal disorders. The disease which seems to occur most frequently in the study area is stomach-ache, gastritis, diarrhoea/ dysentery, and worm infestation. The mode of use is paste in high percentage and root is the plant part which is frequently used.
There were many overlapping of the use of plant species for same ailments in the three VDCs but in some cases the use value in three VDCs was uncommon, for example, in Chilime and Thuman, Aconitum spicatum was used to treat stomach disorder of animal but in Thuman it was used for the treatment of fever. Use of species for fever is similar with the findings of Prasai (2007) done inside the Langtang National Park.

In the study area, herbs are the primary source of medicinal ingredients, followed by trees, most likely because herbs are more abundant. It is believed that the more abundant a plant is the more medicinal virtues it may possess. This is perhaps because herbs and climbers are more accessible, and roots, rhizomes and leaves, which are the most frequently used part of the plant to treat diseases, are easier to reach. They also have a faster rate of growth and renewal and may possess bioactive secondary metabolites in relation to the environment (Bernhoft 2010).

Tamang people of the study villages possess rich indigenous knowledge on utilizing plants for gastrointestinal disorders. The knowledge among people is based on a welldefined traditional practice. The uses of plants are well known among the Tamang healers of the three VDCs studied. These healers are considered to be very effective in treating diseases. Especially for species common among the three VDCs there underlines their well-defined tradition and this could be important for the selection of plants for further phytochemical and bioactivity assays. Medicinal plant resources are the important component of biodiversity with important contributors to local livelihood. Therefore, the conservation of medicinal plants is not only vital to the livelihood of local people but also has immense cultural significance to them.

\section{Acknowledgements}

Our special thanks go to Ethnobotanical Society of Nepal (ESON) for financial support. We are particularly indebted to the members of buffer zone user groups committees and management council for their help to find the relevant information. The local residents of all the three VDCs are highly acknowledged for providing valuable information. Two anonymous reviewers are highly acknowledged. Our thanks are also due to Dr. Suresh Kumar Ghimire for his comments and suggestions in the earlier versions of the manuscript.

\section{References}

Bannerman R.H. 1982. Traditional medicine in modern health care. World Health Forum, 3: 8-13.

Bhattarai S., Chaudhary R.P. and Taylor R.S.L. 2006. Ethnomedicinal plants used by the people of Manang district, Central Nepal. Journal of Ethnobiology and Ethnomedicine, 2: 41 [online] URL: https://doi.org/10.1186/1746-4269-2-41.

Bodeker C., Bodeker G., Ong C.K., Grundy C.K., Burford G. and Shein K. 2005. WHO Global Atlas of Traditional, Complementary 
and Alternative Medicine. World Health Organization, Geneva, Switzerland.

Bernhoft A. 2010. A brief review on bioactive compounds in plants. In: Bioactive Compounds in Plants - Benefits and Risks for Man and Animals (A. Bernhoft, ed.), pp. 11-17. The Norwegian Academy of Science and Letters, Oslo, Norway.

Cunningham A.B. 2001. Applied Ethnobotany: People, Wild Plant Use and Conservation. A People and Plants Conservation Manual. Earth scan, London.

Dangol B.R. 2002. Forest Community Diversity and Associated Medicinal Plants in the Langtang National Park, Rasuwa, Central Nepal. M.Sc. Thesis, Central Department of Botany, Tribhuvan University, Kathmandu, Nepal.

Ekor M. 2013. The growing use of herbal medicines: issues relating to adverse reactions and challenges in monitoring safety. Frontiers in Pharmacology, 2013; 4: 177 [online] URL: https://www.ncbi. nlm.nih.gov/pmc/articles/PMC3887317/pdf/fphar-04-00177.pdf.

Joshi A.R. and Edington J.M. 1990. The use of medicinal plants by two village communities in the Central Development Region of Nepal. Economic Botany, 44: 71-83.

Kunwar R.M. and Bussmann R.W. 2008. Ethnobotany in the Nepal Himalaya. Journal of Ethnobiology and Ethnomedicine, 4: 24 [online] URL: https://doi.org/10.1186/1746-4269-4-24.

Luitel D.R., Rokaya M.B., Timsina B. and Münzbergová Z. 2014. Medicinal plants used by the Tamang community in the Makawanpur district of central Nepal. Journal of Ethnobiology and Ethnomedicine, 10: 5 [online] URL: http:// doi.org/10.1186/1746-4269-10-5

Malla B., Gauchan D.B. and Chhetri R.B. 2015. An ethnobotanical study of medicinal plants used by ethnic people in Parbat district of western Nepal. Journal of Ethnopharmacology, 165: 103-117.

Manandhar N.P. 1980. Some less known medicinal plants of Rasuwa District. International Journal of Crude Drug Research, 18: $147-157$
Manandhar N.P. 1999. Conservation of medicinal plant in Nepalese forests: problems and prospective. Medicinal Plant Conservation, 5: 3-4.

Manandhar N.P. 2002. Plants and People of Nepal. Timber Press, Oregon, USA.

Martin G. 1995. Ethnobotany: A Methods Manual. Chapman and Hall, London, UK.

Prasai D. 2007. Ethnomedicinal Knowledge of Tamang Communities in Rasuwa District, Nepal. M.Sc. Thesis, Central Department of Botany, Tribhuvan University, Kathmandu, Nepal.

Rajbhandari K.R. 2001. Ethnobotany of Nepal. Ethnobotanical Society of Nepal, Kathmandu, Nepal.

Rajbhandary S. and Ranjitkar S. 2006. Herbal Drugs and Pharmacognosy: Monographs on Commercially Important Medicinal Plants of Nepal. Ethnobotanical Society of Nepal, Kathmandu.

Sharma U.R., Malla K.J. and Uprety R.K. 2004. Conservation and management efforts of medicinal and aromatic plants in Nepal. Banko Jankari, 14: 3-11.

Shrestha I., Joshi N. and Shrestha K. 2002. Report on some plants from Langtang National Park, Nepal. Journal of Natural History Museum, 21: 79-92.

Shrestha K.K., Tiwari N.N. and Ghimire S.K. 2001. MAPDON - Medicinal and aromatic plant database of Nepal. In: The Himalayan Plants, can they Save Us? Proceeding of Nepal- Japan Joint Symposium on Conservation and Utilization of Himalayan Medicinal Sources, 6-11 November, 2000 (T. Watanabe, A. Takano, M.S. Bista and H.K. Saiju, eds), pp. 53-74. Society for the Conservation and Development of Himalayan Medicinal Resources (SCDHMR), Japan.

Thokar R. 2008. Tamang: a sociolinguistic scenario. Nepalese Linguistics, 23: 391-407. 


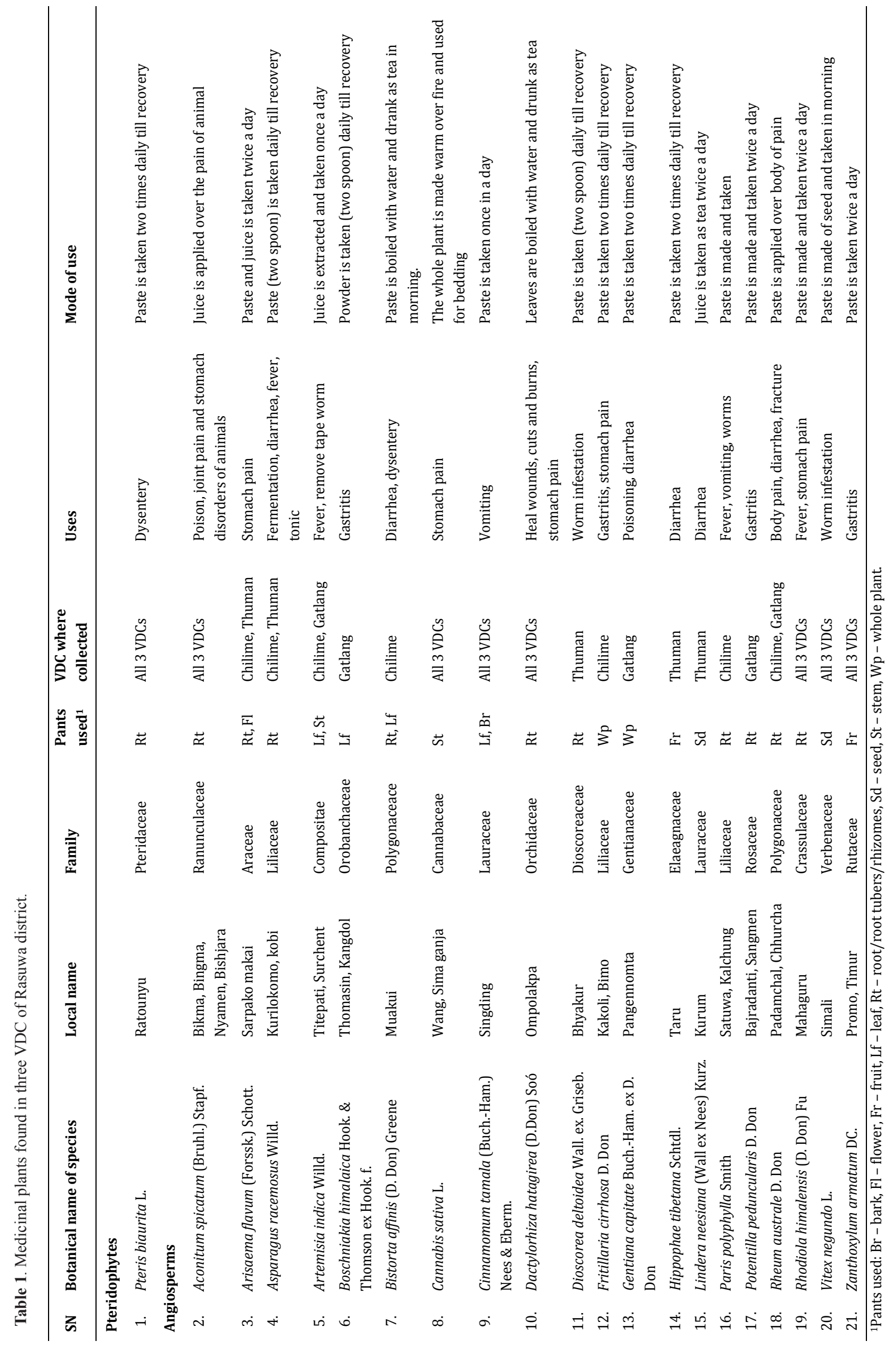

